\title{
The role of polyamine metabolism in dimorphism of Yarrowia lipolytica
}

\author{
Lorenzo Guevara-Olvera ${ }^{2,3}$, Carlos Calvo-Mendez ${ }^{1,3}$ and Jose Ruiz-Herrera ${ }^{1,2 *}$ \\ ${ }^{1}$ Departamento de Genética y Biologia Molecular (Unidad México, D.F.) and ${ }^{2}$ Departamento de Ingenieria Genética \\ (Unidad Irapuato), Centro de Investigación y de Estudios Avanzados del Instituto Politécnico Nacional, Apartado \\ Postal 629, Irapuato, Mexico \\ ${ }^{3}$ Instituto de Investigación en Biología Experimental, Universidad de Guanajuato, Mexico
}

(Received 30 July 1992; revised 3 November 1992; accepted 5 November 1992)

\begin{abstract}
We have devised a convenient procedure to induce the yeast-to-mycelium transition of Yarrowia lipolytica in conditions which avoid the occurrence of the reverse process during the period of study. Yeast cells in late exponential phase were resuspended in water and cooled down to $4^{\circ} \mathrm{C}$ for at least $15 \mathrm{~min}$, then heat-shocked by inoculation into a pre-warmed $\left(30^{\circ} \mathrm{C}\right)$ medium containing $\mathrm{N}$-acetyl-D-glucosamine. Under these conditions, yeast cells developed into large branching filaments which continued elongating for more than $24 \mathrm{~h}$. Further, ornithine decarboxylase (ODC) activity and polyamine cell pools increased compared to those of cells maintained in glucose medium, which continued yeast-like growth. Addition of ODC inhibitors blocked mycelial development, but only if added during a critical initial period after which they had no effect. At effective concentrations, ODC inhibitors had no significant effect on cell growth. Comparative studies of intact and permeabilized cells suggest that this selective effect is probably due to the location of ODC in more than one cell compartment, one of them being inaccessible to the drugs. Blocking of the morphological transition by ODC inhibitors was specifically reversed by putrescine, and by growing the cells in the presence of 5-azacytidine. It is suggested that the effect of the latter compound is related to its capacity to inhibit DNA methylation, indicating a relationship between polyamines and DNA methylation at the onset of the differentiation process.
\end{abstract}

\section{Introduction}

Several species of fungi are characterized by dimorphism, which is the capacity for mycelial or yeast-like growth depending on the environmental conditions. This property is not restricted to specific taxonomic groups, but is shared by organisms representative of Basidiomycetes, Ascomycetes, Zygomycetes and Imperfect Fungi. Interestingly, many pathogenic fungal species are dimorphic, presenting different morphologies in the host and during saprophytic existence (Szaniszlo, 1985). In Candida albicans, dimorphism appears to be related somehow to virulence (Soll, 1985; Odds, 1988). Dimorphism has been considered an interesting model for the study of cell differentiation (Bartnicki-Garcia, 1963).

*Author for correspondence. Tel. 5246251600 ; fax 5246251282.

Abbreviations: AC, 5-azacytidine; DAB, 1,4 diamino-2-butanone; DFMO, $\alpha$-diffuoromethyl ornithine; GlcNAc, $N$-acetyl-D-glucosamine; MO, $\alpha$-methyl ornithine; ODC, ornithine decarboxylase.
Yarrowia lipolytica is a dimorphic organism which grows as a mixture of yeast-like and short mycelial cells in solid and liquid media. Study of environmental factors involved in the regulation of the dimorphic transition (Rodriguez \& Dominguez, 1984) indicated that when $\mathrm{N}$-acetylglucosamine (GlcNAc) was used as the carbon source, cell growth was mostly mycelial, whereas in the presence of glucose it was yeast-like. $Y$. lipolytica appears to be a useful model for the study of dimorphism in fungi, since in contrast to other dimorphic species, it has a sexual cycle (Wickerham et al., 1970) and can be used as a subject for genetic manipulation (Gaillardin et al., 1973; Ogrydziak et al., 1978); and transformation (Gaillardin et al., 1976; Cheng \& Ogrydziak, 1987).

Studies from our laboratory on cell differentiation in fungi have demonstrated the importance of polyamine metabolism in these phenomena, including the dimorphic transitions of Mucor rouxii (Martinez-Pacheco et al., 1989) and C. albicans (Martinez et al., 1990). Polyamines play an important role in cell growth and development of almost all organisms (Heby, 1981; Tabor \& Tabor, 1984, 1985; Smith, 1985), although their precise mode of 
action remains unknown. We have investigated the importance of polyamines in the dimorphic transition of Yarrowia, using some inhibitors of poly biosynthesis, as a first approach to studying dimorphism in this organism.

\section{Methods}

Fungal strain and growth conditions. Yarrowia lipolytica CX 39-74A was obtained from A. Dominguez of the University of Salamanca, Spain. It was maintained by periodic transfer to slants of YED medium containing $1 \%$ yeast extract, $2 \%$ glucose and $2 \%$ agar (all $\mathrm{w} / \mathrm{v}$ ) and incubating at $26^{\circ} \mathrm{C}$. Yeast cells were obtained by inoculating a loopful into $25 \mathrm{ml}$ of liquid Yeast Nitrogen Base (YNB)-glucose medium and shaking (250 r.p.m.) at $28^{\circ} \mathrm{C}$. YNB medium was prepared from its components according to the formulation described in the Difco manual. Seven different solutions of the following composition (per $100 \mathrm{ml}$ ) were prepared: (1) biotin, $2 \mathrm{mg}$; folic acid, $2 \mathrm{mg}$; (2) pantothenic acid, $4 \mathrm{mg}$; inositol, $20 \mathrm{mg}$; p-aminobenzoic acid, $2 \mathrm{mg}$; pyridoxin, $4 \mathrm{mg}$; riboflavin, $2 \mathrm{mg}$; thiamin, $4 \mathrm{mg}$; niacin, $4 \mathrm{mg}$; (3) boric acid, $50 \mathrm{mg}$; $\mathrm{CuSO}_{4}, 4 \mathrm{mg}$; KI, $10 \mathrm{mg} ; \mathrm{FeCl}_{3}, 20 \mathrm{mg} ; \mathrm{MnCl}_{2}$, $40 \mathrm{mg} ; \mathrm{Na}_{2} \mathrm{MoO}_{4}, 20 \mathrm{mg} ; \mathrm{ZnSo}_{4}, 40 \mathrm{mg}$. These solutions were sterilized by filtration through Millipore filters of $0.45 \mu \mathrm{m}$ pore diameter. (4) $\mathrm{MgSO}_{4}, 1.25 \mathrm{~g} ; \mathrm{NaCl}, 0.25 \mathrm{~g} ; \mathrm{CaCl}_{2}, 0.25 \mathrm{~g}$; (5) $\left(\mathrm{NH}_{4}\right)_{2} \mathrm{SO}_{4}, 5 \mathrm{~g}$; $\mathrm{KH}_{2} \mathrm{PO}_{4}, 1 \mathrm{~g}$; (6) glucose, $10 \mathrm{~g}$; or GlcNAc, $10 \mathrm{~g}$; (7) $1 \mathrm{~m}$-citric acid adjusted to $\mathrm{pH} 6.0$ with saturated $\mathrm{NaOH}$. Solutions were mixed in the following proportion: $1,0.1 \mathrm{ml} ; 2,10 \mathrm{ml} ; 3,1 \mathrm{ml} ; 4,40 \mathrm{ml} ; 5,100 \mathrm{ml}$; $6,100 \mathrm{ml}$. Citrate buffer solution (no. 7, $50 \mathrm{ml}$ per 1) was added only when GlcNAc was used as the carbon source. The medium was taken to 1 litre with distilled water and sterilized by Millipore filtration. Storage of solutions 1 and 2 for more than 1 month at $4{ }^{\circ} \mathrm{C}$ led to a reduction in cell growth as well as in the proportion of mycelial cells. For this reason they were used not more than one month after being prepared.

Mycelial growth. The inocula used were yeast cells grown for $12 \mathrm{~h}$ as described above. Cells were harvested by centrifugation at room temperature, washed with sterile distilled water and inoculated at a final density of $3 \times 10^{6}$ cells per $\mathrm{ml}$ in YNB medium which contained $0.5 \%$ GlcNAc instead of glucose, as carbon source (YNBGlcNAc, see above). Alternatively, cells were washed with ice-cold sterile distilled water, maintained at $4{ }^{\circ} \mathrm{C}$ for various periods of time (see Results), and inoculated into pre-warmed medium. Cells were incubated at $30^{\circ} \mathrm{C}$ in a water bath shaken at 250 r.p.m. for various periods of time.

Determination of cell morphology. Samples of the media were withdrawn and treated with formaldehyde. Cells were counted with a haemocytometer and morphology of no fewer than 200 cells was scored using a phase-contrast microscope. Cells were considered mycelial when they had a well-defined slender germ tube longer than the large diameter of the mother cell.

Determination of cell growth. Cells were sedimented by centrifugation, washed with water and resuspended in $1 \mathrm{M}-\mathrm{NaOH}$. Protein was measured by the Lowry method using BSA as standard. Cell number was assessed by direct count (see above) or by turbidity, using a standard curve which related $\mathrm{OD}_{600}$ to cell numbers, measured with a haemocytometer.

Determination of ornithine decarboxylase (ODC) activity. The method described by Calvo-Mendez et al. (1987), which is a modification of the technique described by Sissions et al. (1976), was used. Whole or permeabilized cells were incubated in PDP buffer (see below) at $30^{\circ} \mathrm{C}$, and $\mathrm{CO}_{2}$ was trapped using $\mathrm{NaOH}$. Activity was expressed as nmol $\mathrm{CO}_{2}$ evolved in one min. Specific activity was related to one $\mathrm{mg}$ of cell protein. When necessary, cells were permeabilized by the method described by Adams (1972). Cells were centrifuged, washed and resuspended in $40 \%(\mathrm{v} / \mathrm{v})$ DMSO in water and shaken in a Vortex mixer for 6 periods of $20 \mathrm{~s}$ each with intermediate cooling in an ice bath. Cells were washed three times by centrifugation with $20 \mathrm{~mm}-$ phosphate buffer, pH 7.3, containing 2 mM-DTT and $0 \cdot 2$ mM-pyridoxal phosphate (PDP buffer).

Determination of polyamine concentration. The procedure for polyamine extraction was the one described by Torrigiani et al. (1980), which separates the compounds into three classes: free, conjugated and bound. Determination of polyamines of each class was performed by TLC separation of the dansyl derivatives as described by CalvoMendez et al. (1987). Concentrations are expressed as nmol polyamine $(\mathrm{mg} \text { cell protein })^{-1}$.

\section{Results}

Mycelial growth of Yarrowia lipolytica can be induced by a simple change in the carbon source (Rodriguez \& Dominguez 1984). Whereas cultivation in a glucose medium leads to yeast growth, the substitution of GlcNAc induces mycelial growth (Fig. 1). Yeast cells of $Y$. lipolytica are rather elongated and a clear differentiation from mycelial cells can be ascertained only after germ tubes are rather long, a property attained after several hours of growth in GlcNAc-containing medium. However, as already noted by Rodriguez \& Dominguez (1984), after some time of incubation the proportion of mycelial cells in YNBGlcNAc medium started to decrease (Fig. 2). This decrease was not due to the disappearance of mycelial cells or to mycelial-to-yeast conversion, but to the active reproduction of those yeasts which had not originally responded to the morphogenetic stimulus. This effect causes confusion whenever the effect of environmental conditions on dimorphism is studied. We therefore looked for conditions which avoided this phenomenon. Starving the cells in distilled water at $4{ }^{\circ} \mathrm{C}$ for variable periods of time induced mycelial growth when they were inoculated into medium containing glucose as carbon source. This effect was dependent on growth temperature and was maximal at $30^{\circ} \mathrm{C}$. At higher temperatures both cell growth and yeast-mycelial transition decreased (not shown). However, the mycelial proportion never exceeded $55 \%$ of the total population. Combined use of both starvation and growth on GlcNAc gave optimal results. About $90 \%$ of the cell population germinated as mycelium, and their proportion remained constant for $24 \mathrm{~h}$ (Fig. 2, see also Fig. 1). Continued incubation up to $48 \mathrm{~h}$ gave rise to extremely long and branched filaments without an increase in yeast numbers (results not shown). This result suggests that the remaining yeast cells must be dead since they are unable to bud.

Further studies revealed that the starvation period was not necessary to induce mycelial growth. The mere cooling of cells (the minimum period tested was $15 \mathrm{~min}$ ) 


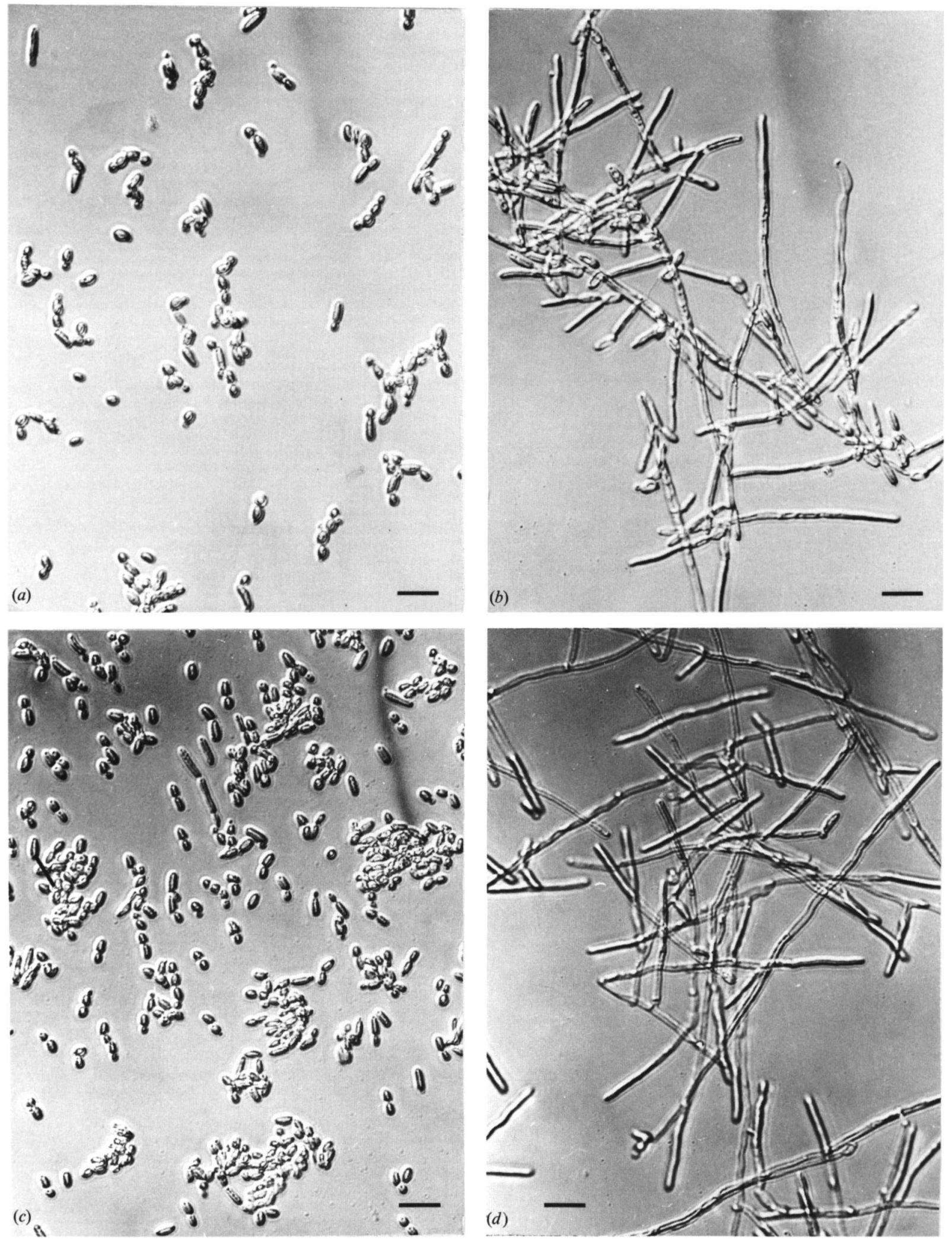

Fig. 1. Morphology of Yarrowia lipolytica grown as yeast in YNBGlc medium ( $a$ and $c$ ), or as mycelium in YNBGlcNAc medium, after a heat-shock $(b$ and $d)$, after $12 \mathrm{~h}(a, b)$ or $24 \mathrm{~h}(c, d)$ incubation. Bar, $10 \mu \mathrm{m}$. 


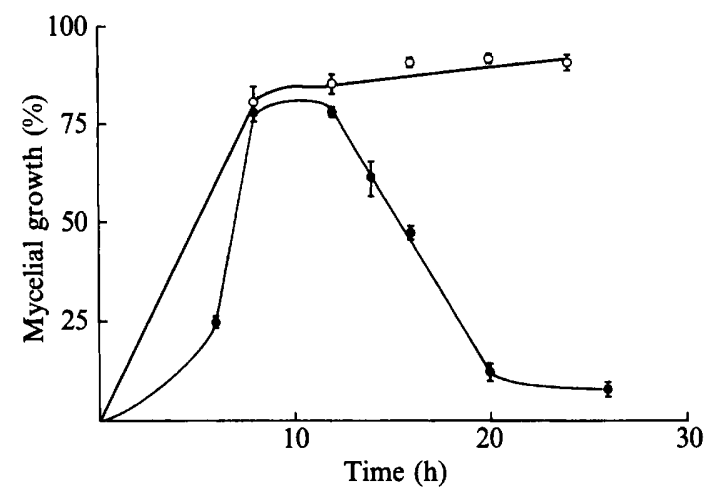

Fig. 2. Dimorphic transition of Yarrowia lipolytica in YNBGlcNAc medium. Filled circles: yeast cells grown for $12 \mathrm{~h}$ in YNBGlc medium, harvested at room temperature, inoculated $\left(3 \times 10^{6}\right.$ cells ml $\left.{ }^{-1}\right)$ into YNBGlcNAc medium and incubated with shaking at $28^{\circ} \mathrm{C}$. Open circles: cells grown for $12 \mathrm{~h}$ in YNBGlc medium, harvested at $4{ }^{\circ} \mathrm{C}$, washed with ice-cold distilled water and maintained at $4{ }^{\circ} \mathrm{C}$ for $15 \mathrm{~min}$, then inoculated into warm $\left(30^{\circ} \mathrm{C}\right)$ medium $\left(3 \times 10^{6}\right.$ cells ml $\left.{ }^{-1}\right)$ and incubated with shaking at the same temperature. At intervals, samples were withdrawn and cell morphology was determined. Data are means of three different experiments; bars indicate standard deviations.

and their further resuspension into medium maintained at $30^{\circ} \mathrm{C}$ gave almost identical results. The heat shock, and not starvation, appears to cause the induction of mycelial growth.

Transfer of yeast cells after a heat shock to GlcNAccontaining medium gave rise to a sudden increase in ornithine decarboxylase (ODC) activity. This increase was almost absent when cells were recovered at $24^{\circ} \mathrm{C}$ and transferred to a medium with glucose as the carbon source (Fig. 3).

Accompanying the increase in ODC levels, there was also a build-up in polyamines (mainly free and conjugated) as compared to inoculum cells (Table 1). Levels of bound polyamines on the other hand, decreased. More total polyamines were synthesized by mycelial than

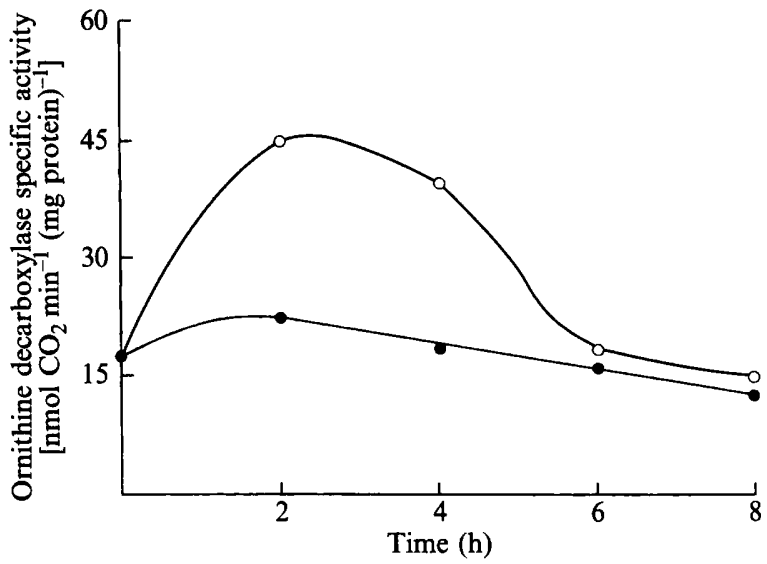

Fig. 3. ODC activity during the growth of Yarrowia lipolytica. Yeast cells were grown in YNBGlc medium at $28^{\circ} \mathrm{C}$ for $12 \mathrm{~h}$. One set of samples was maintained at this temperature; the others were kept at $4{ }^{\circ} \mathrm{C}$ for $15 \mathrm{~min}$. Cells $\left(3 \times 10^{6} \mathrm{ml}^{-1}\right)$ were then inoculated into YNBGlc or YNBGlcNAc media, respectively, and incubated at $30^{\circ} \mathrm{C}$. At intervals, duplicate $50 \mathrm{ml}$ samples were removed, and the cells were centrifuged, washed with PDP buffer and resuspended in PDP buffer. ODC activity was measured as described in Methods. Open circles: cells incubated in YNBGlcNAc medium. Filled circles: cells incubated in YNBGlc medium. Data are means of two different experiments.

by yeast cells, and the highest differences were those for spermidine and free putrescine.

We tested the effect of two ODC inhibitors on the activity of the enzyme. These were 1,4-diamino2-butanone (DAB) and $\alpha$-difluoromethylornithine (DFMO). They were added to two kinds of preparations; whole cells or cells permeabilized with DMSO. Other permeabilization methods which made use of toluene or digitonin, or preparation of cell-free extracts by shaking the cells with glass beads in a Braun homogenizer or by use of a sonicator lowered enzyme activity. The response of whole or permeabilized cells to the inhibitors was quite distinct. In whole cells, DAB or DFMO produced

Table 1. Polyamine content of Yarrowia lipolytica

Yeast cells grown in YNBGlc medium were inoculated into fresh medium to obtain either yeasts (YNBGlc) or mycelium (YNBGlcNAc, heat shocked). Samples of the inoculum and cells grown for $2 \mathrm{~h}$ under either set of conditions were recovered, and free, bound and conjugated polyamines were measured. Two sets of values are shown. Each is a mean value from two different experiments performed with triplicate samples, expressed as nmol polyamine (mg cell protein) ${ }^{-1}$.

\begin{tabular}{|c|c|c|c|c|c|c|c|c|c|c|c|c|}
\hline \multirow[b]{2}{*}{ Sample } & \multicolumn{4}{|c|}{ Putrescine } & \multicolumn{4}{|c|}{ Spermidine } & \multicolumn{4}{|c|}{ Spermine } \\
\hline & Free & Conj. & Bound & Total & Free & Conj. & Bound & Total & Free & Conj. & Bound & Total \\
\hline \multirow[t]{2}{*}{ Inoculum } & 0.4 & $1 \cdot 7$ & 7.9 & $10 \cdot 0$ & $2 \cdot 1$ & 0.4 & $15 \cdot 9$ & $18 \cdot 4$ & $1 \cdot 4$ & 0.5 & $8 \cdot 3$ & $10 \cdot 2$ \\
\hline & 0.6 & $2 \cdot 2$ & $8 \cdot 5$ & $11 \cdot 3$ & 3.7 & 0.7 & $17 \cdot 6$ & $22 \cdot 0$ & 1.2 & 0.6 & $10 \cdot 7$ & 12.5 \\
\hline \multirow[t]{2}{*}{ Yeasts } & $5 \cdot 0$ & $4 \cdot 5$ & $3 \cdot 6$ & $12 \cdot 6$ & $12 \cdot 2$ & $9 \cdot 3$ & $5 \cdot 2$ & $26 \cdot 7$ & $5 \cdot 2$ & 6.8 & $8 \cdot 1$ & $20 \cdot 1$ \\
\hline & $3 \cdot 3$ & $3 \cdot 3$ & $5 \cdot 1$ & 11.7 & 6.5 & 8.6 & 3.7 & $18 \cdot 8$ & $6 \cdot \overline{2}$ & 5.9 & $12 \cdot 4$ & 24.5 \\
\hline \multirow{2}{*}{ Mycelium } & $8 \cdot 6$ & 0.9 & 4.7 & $14 \cdot 2$ & $15 \cdot 0$ & $21 \cdot 5$ & 6.4 & $42 \cdot 9$ & $4 \cdot 1$ & $8 \cdot 8$ & $6 \cdot 3$ & $19 \cdot 2$ \\
\hline & $8 \cdot 1$ & 0.5 & $5 \cdot 2$ & 13.8 & 12.5 & 19.7 & $4 \cdot 3$ & $36 \cdot 5$ & $5 \cdot 5$ & 8.9 & $7 \cdot 8$ & 22.2 \\
\hline
\end{tabular}


Table 2. Effect of DAB and DFMO on ornithine decarboxylase activity of intact and permeabilized cells of Yarrowia lipolytica

Mycelial cells grown in YNBGIcNAc medium for $8 \mathrm{~h}$ were harvested by centrifugation and divided into two aliquots. One of them remained as the control, whereas the other was treated with DMSO as described in Methods. Ornithine decarboxylase activity was measured and expressed as $\mathrm{nmol} \mathrm{CO}_{2}$ liberated per min per $\mathrm{mg}$ cell protein. Results are means $\pm \mathrm{SEM}$ of at least 3 experiments.

\begin{tabular}{|c|c|c|c|c|}
\hline \multirow[b]{2}{*}{ Inhibitor } & \multicolumn{2}{|c|}{ Intact cells } & \multicolumn{2}{|c|}{ DMSO-treated cells } \\
\hline & Activity & Inhibition (\%) & Activity & Inhibition (\%) \\
\hline None & $15 \cdot 7 \pm 2 \cdot 7$ & - & $24 \cdot 4 \pm 3 \cdot 2$ & - \\
\hline $0.1 \mathrm{mM}$ DAB & $19 \cdot 2 \pm 1 \cdot 1$ & 0 & $6.3 \pm 0.6$ & $74 \cdot 2 \pm 1 \cdot 1$ \\
\hline $1.0 \mathrm{~mm}-\mathrm{DAB}$ & $20.7 \pm 2.1$ & 0 & $2 \cdot 2+0.1$ & $91 \cdot 5+1.5$ \\
\hline $20 \mathrm{~mm}-\mathrm{DAB}$ & $10.0+1.6$ & $29 \cdot 3+1.9$ & $2 \cdot 4+0.2$ & $88 \cdot 3+2 \cdot 0$ \\
\hline $1.0 \mathrm{~mm}$-DFMO & ND & $\mathrm{ND}$ & $2 \cdot 2 \pm 0 \cdot 1$ & $91.5 \pm 1.5$ \\
\hline $40 \mathrm{~mm}-\mathrm{DFMO}$ & $11.6 \pm 0.8$ & $31 \cdot 1 \pm 0 \cdot 8$ & $1 \cdot 8 \pm 0 \cdot 1$ & $94 \cdot 0 \pm 2 \cdot 4$ \\
\hline
\end{tabular}

ND, not determined.

Table 3. Effect of ornithine decarboxylase inhibitors on yeast-mycelial transition of Yarrowia lipolytica

Cells were grown for $12 \mathrm{~h}$ in YNBGlc medium, centrifuged, washed, resuspended in water and kept at $4^{\circ} \mathrm{C}$. They were inoculated into YNBGICNAc medium in the presence or absence of the indicated inhibitors at a cell density of $3 \times 10^{6}$ cells per $\mathrm{ml}$, and incubated at $30^{\circ} \mathrm{C}$ for $12 \mathrm{~h}$. Cell growth and cell morphology were measured. The data for DAB and DFMO are means \pm SEM of four experiments. MO values are means of two different experiments.

\begin{tabular}{lcccc}
\hline \hline & & & \multicolumn{2}{c}{ Yeast-mycelium } \\
\cline { 3 - 5 } & $\begin{array}{c}\text { Growth } \\
\left(\mu \mathrm{g} \mathrm{protein}_{\text {Inhibitor }}\right.\end{array}$ & $\begin{array}{c}\text { Inhibition } \\
\left.\mathrm{ml}^{-1}\right)\end{array}$ & $\begin{array}{c}\text { transition } \\
(\%)\end{array}$ & $\begin{array}{c}\text { inhibition } \\
(\%)\end{array}$ \\
\hline None & $314 \pm 60$ & - & $90 \pm 4$ & - \\
$10 \mathrm{mM}-\mathrm{OAB}$ & $297 \pm 70$ & $12 \pm 5 \cdot 5$ & $30 \pm 2 \cdot 5$ & $67 \pm 3$ \\
$15 \mathrm{mM}-\mathrm{DAB}$ & $296 \pm 60$ & $9 \pm 3 \cdot 5$ & $21 \pm 4$ & $77 \pm 3$ \\
$20 \mathrm{mM}-\mathrm{DAB}$ & $289 \pm 70$ & $12 \pm 5 \cdot 5$ & $14 \pm 3$ & $84 \pm 2 \cdot 5$ \\
None & $534 \pm 130$ & - & $77 \pm 3$ & - \\
$40 \mathrm{mM}-\mathrm{DFMO}$ & $483 \pm 120$ & $10 \pm 1 \cdot 0$ & $14 \pm 3 \cdot 5$ & $78 \pm 7 \cdot 5$ \\
None & 720 & - & 81 & - \\
$40 \mathrm{mM}-\mathrm{MO}$ & 780 & 0 & 57 & 30 \\
$70 \mathrm{mM}-\mathrm{MO}$ & 560 & 22 & 43 & 47 \\
$100 \mathrm{mM}-\mathrm{MO}$ & 519 & 28 & 13 & 84 \\
\hline \hline
\end{tabular}

at most $30 \%$ inhibition at the highest concentrations used ( 20 or $40 \mathrm{~mm}$, respectively). ODC activity in permeabilized cells, on the other hand, was inhibited about $90 \%$ by such concentrations (Table 2). In addition, 1 mM-DFMO and $1 \mathrm{mM}$-DAB gave comparable levels of inhibition (Table 2). The low inhibition of ODC in whole cells was not due to the short time of contact between the drug and the cells. Preincubation of the cells with DAB or DFMO for 2 or $4 \mathrm{~h}$ did not increase the level of inhibition of ODC (not shown).

Based on these results, we tested the effect of ODC inhibitors on the morphogenetic transition of the fungus.

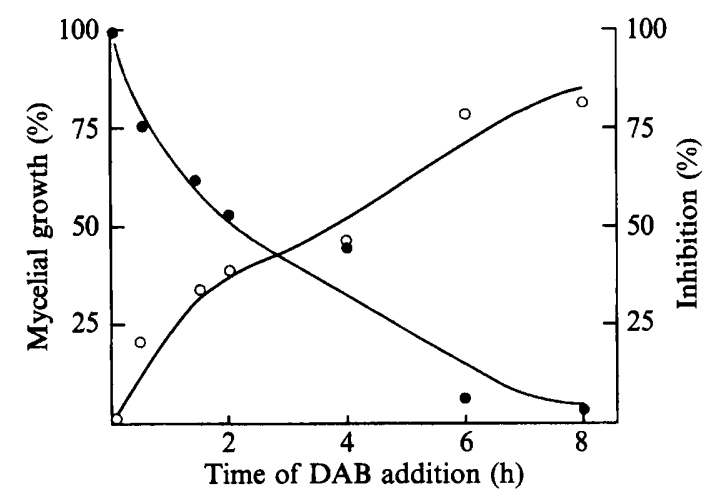

Fig. 4. Sensitivity of mycelial induction to DAB as a function of incubation time. Yeast cells maintained in the cold were transferred to YNBGlcNAc medium. At the indicated periods of time, DAB was added to sets of flasks. After $12 \mathrm{~h}$ incubation, cell morphology was scored $(O)$, and inhibition of mycelial transition was calculated (O). Data are means of two different experiments.

The inhibitors used were DAB, DFMO and $\alpha$-methylornithine (MO). All were strong inhibitors of the dimorphic transition, at concentrations which caused almost no inhibition of cell growth (Table 3). Concentrations even higher than those used in the experiments described in Table 2 did not affect yeast growth (not shown).

The time of addition of the inhibitors during incubation in YNBGlcNAc was decisive for its morphogenetic effect (Fig. 4). When the drug was added after $4 \mathrm{~h}$ of growth, at which time the dimorphic transition is not yet discernible, its inhibitory effect was reduced to about $30-40 \%$ of that when it was added to the medium together with the inoculum. When DAB was added after $6 \mathrm{~h}$ incubation, it had no effect on mycelial development and mycelial cells observed after 12 or $24 \mathrm{~h}$ were indistinguishable from those of the control without drug. 
Table 4. Effect of DAB addition to the inoculum on the yeast-mycelial transition of Yarrowia lipolytica

Cells were grown for $12 \mathrm{~h}$ in YNBGlc medium in the presence or absence of DAB. Cells were then harvested by centrifugation, washed and resuspended in cold water. After $15 \mathrm{~min}$, cells $\left(3 \times 10^{6}\right.$ per $\mathrm{ml}$ ) were inoculated into YNBGlcNAc medium and grown at $30^{\circ} \mathrm{C}$. After $12 \mathrm{~h}$, cell growth and morphology were measured. Data for 0.5 and 1.0 mM-DAB are means \pm SEM of three different experiments. Data for 10 and $20 \mathrm{~mm}-\mathrm{DA} B$ are means of two different experiments.

\begin{tabular}{ccccc}
\hline \hline & & \multicolumn{2}{c}{ Yeast-mycelia } \\
\cline { 4 - 5 } $\begin{array}{c}\text { DAB } \\
\text { concentration } \\
(\mathrm{mM})\end{array}$ & $\begin{array}{c}\text { Growth } \\
(\mu \mathrm{g} \text { protein } \\
\left.\mathrm{ml}^{-1}\right)\end{array}$ & $\begin{array}{c}\text { Inhibition } \\
(\%)\end{array}$ & $\begin{array}{c}\text { Transition } \\
(\%)\end{array}$ & $\begin{array}{c}\text { Inhibition } \\
(\%)\end{array}$ \\
\hline None & $453 \pm 40$ & - & $82 \pm 1 \cdot 5$ & - \\
0.5 & $540 \pm 110$ & 0 & $24 \pm 2 \cdot 5$ & $71 \pm 2 \cdot 5$ \\
$1 \cdot 0$ & $458 \pm 55$ & 0 & $17 \pm 1 \cdot 5$ & $80 \pm 2$ \\
$10 \cdot 0$ & 410 & 9 & 0 & 100 \\
20.0 & 400 & 12 & 0 & 100 \\
\hline
\end{tabular}

Table 5. Partial reversal of the effect of $D A B$ by putrescine

Yeast cells were grown for $12 \mathrm{~h}$ in YNBGlc medium containing $20 \mathrm{~mm}-\mathrm{DAB}$, harvested, washed and resuspended in cold water. After 15 min they were inoculated into YNBGlcNAc medium in the presence or absence of putrescine. After $12 \mathrm{~h}$, cell growth and morphology were determined. Values are means \pm SEM of three different experiments.

\begin{tabular}{ccc}
\hline \hline $\begin{array}{c}\text { Putrescine } \\
(\mathrm{mM})\end{array}$ & $\begin{array}{c}\text { Growth } \\
(\mu \mathrm{g} \text { protein } \\
\left.\mathrm{ml}^{-1}\right)\end{array}$ & $\begin{array}{c}\text { Mycelial } \\
\text { transition } \\
(\%)\end{array}$ \\
\hline None & $184 \pm 18$ & $5 \pm 1$ \\
0.25 & $456 \pm 46$ & $38 \pm 3$ \\
0.50 & $495 \pm 98$ & $44 \pm 4$ \\
0.75 & $422 \pm 118$ & $47 \pm 4$ \\
\hline \hline
\end{tabular}

These results indicate that the morphogenetic signal blocked by the ODC inhibitors operates at an early period. Also, it was not necessary for ODC inhibitors to be present during incubation in mycelial-induction medium for them to be effective. Concentrations even lower than those effective when added to YNB-GlcNAc inhibited mycelial growth if added to the medium where the inoculum was grown (Table 4).

This observation was used as the basis to determine whether the effect of ODC inhibitors was specific or not. Cells were grown in the presence of $20 \mathrm{~mm}-\mathrm{DAB}$ in YNBGlc medium. The resulting yeasts were harvested and after holding at $4{ }^{\circ} \mathrm{C}$, they were inoculated into YNBGlcNAc medium containing different concentrations of putrescine. When putrescine-free medium was used, only $5 \%$ of the inoculated cells turned into mycelium, whereas the inclusion of $0.25-0.75 \mathrm{mM}-$ putrescineincreased growth and the proportion of mycelial cells to $40-50 \%$ (Table 5). Higher concentrations of
Table 6. Partial reversal of the effect of $D A B$ by 5-azacytidine

Yeast cells of $Y$. lipolytica were grown in YNBGlc medium for $8 \mathrm{~h}$, then $\mathrm{AC}$ was added to some of the cultures, and incubation was continued for $4 \mathrm{~h}$. Cells were harvested by centrifugation, washed, and maintained for $12 \mathrm{~h}$ in $\mathrm{AC}$ solution at $4{ }^{\circ} \mathrm{C}$. They were then centrifuged, washed, and inoculated $\left(3 \times 10^{6}\right.$ per $\left.\mathrm{ml}\right)$ into YNBGlcNAc medium in the presence or absence of $20 \mathrm{~mm}$-DAB and incubated at $30^{\circ} \mathrm{C}$. After $12 \mathrm{~h}$, cell growth and morphology were determined. Values are means \pm SEM of three different experiments.

\begin{tabular}{cccc}
\hline \hline $\begin{array}{c}\text { AC added to } \\
\text { inoculum } \\
(\mu \mathrm{M})\end{array}$ & $\begin{array}{c}\text { DAB added to } \\
\text { growth medium }\end{array}$ & $\begin{array}{c}\text { Growth } \\
(\mu \mathrm{g} \text { protein } \\
\left.\mathrm{ml}^{-1}\right)\end{array}$ & $\begin{array}{c}\text { Mycelial } \\
\text { transition } \\
(\%)\end{array}$ \\
\hline None & None & $510 \pm 46$ & $83 \pm 1$ \\
None & $20 \mathrm{mM}$ & $420 \pm 6$ & $8 \pm 0$ \\
$2 \cdot 0$ & $20 \mathrm{mM}$ & $421 \pm 21$ & $27 \pm 2$ \\
$5 \cdot 0$ & $20 \mathrm{mM}$ & $270 \pm 21$ & $71 \pm 2$ \\
$10 \cdot 0$ & $20 \mathrm{mM}$ & $224 \pm 20$ & $29 \pm 6$ \\
\hline \hline
\end{tabular}

putrescine were inhibitory for cell growth and did not give rise to higher mycelial ratios. Mycelial cells formed in the medium containing putrescine were much longer than those observed in putrescine-free medium.

The effect of ODC inhibitors was reversed not only by putrescine, but also by the DNA-methylation inhibitor, 5-azacytidine (AC). The drug was extremely toxic, however, and its inhibitory effect was increased when added simultaneously with DFMO or DAB. Therefore, a special protocol had to be designed to measure the effect of AC on the inhibitory effect of DAB. After several trials, the following protocol was used: cells were grown in the yeast form for $8 \mathrm{~h}$ in the absence of any drug; AC was then added to the medium, and incubation continued for $4 \mathrm{~h}$. Cells were harvested by centrifugation, washed and resuspended in a solution of AC. After $12 \mathrm{~h}$ at $4{ }^{\circ} \mathrm{C}$, cells were centrifuged, $A C$ was washed out, and the cells were inoculated into DAB-containing medium. The results are shown in Table 6 . When cells were grown in AC-free medium and then resuspended into YNBGlcNAc medium containing $20 \mathrm{~mm}-\mathrm{DAB}$, mycelial cells were decreased from $83 \%$ in the control, to less than $8 \%$ of stunted mycelial cells. But when $5 \mu \mathrm{M}-\mathrm{AC}$ was included into YNBGlcNAc medium, the proportion of mycelial cells increased to $71 \%$, and these mycelial cells were as long as those present in control cultures. Higher concentrations of $\mathrm{AC}$ were less effective in reversing the DAB effect, probably because of their toxicity.

\section{Discussion}

The similarities in the factors which affect the yeast-tomycelium transition in Yarrowia lipolytica and Candida albicans are noticeable. Both organisms show mycelial growth when incubated in media containing GlcNAc 
(Simonetti et al., 1974; Rodriguez \& Dominguez, 1984). In C. albicans, starvation predisposes the cells to grow as mycelium when they are further incubated at $37^{\circ} \mathrm{C}$ (Soll, 1985). Similarly, we found that cells starved in plain water at $4{ }^{\circ} \mathrm{C}$ showed mycelial growth when transferred to a glucose-containing medium. The inducers appeared to be synergistic: when starved cells were inoculated into GlcNAc-containing medium, almost all the cells grew as mycelium. The small and constant proportion of yeast cells remaining under such conditions probably represent the non-viable cells originally present in the cultures. The effect of cooling and further heating of the cells appears to be related not to starvation or to synchronization in the cell cycle as suggested for C. albicans (Soll, 1985), but to a heat-shock phenomenon. Heat-shock induces the synthesis of specific heat-shock proteins ( $\mathrm{HsP}$ ) in almost all systems (Lindquist, 1986) including C.albicans (Dabrowa \& Howard, 1984; Zeuthen \& Howard, 1984). These proteins may well play a role in cell differentiation. However, the alternative that a heat-labile repressor of myceliation is destroyed during the heat-shock cannot yet be dismissed.

Polyamines are important factors involved in cell proliferation and differentiation in a great number of systems (Heby, 1981; Tabor \& Tabor, 1984, 1985), including fungi (Stevens \& Winther, 1979). During differentiation the activity of the key regulatory enzyme for polyamine synthesis, ornithine decarboxylase (ODC), is increased several-fold. ODC activity increases during the germination of the spores of Blastocladiella emersonii, Aspergillus nidulans, Neurospora crassa, Rhizopus stolonifer, Botryodiplodia sp., Dictyostelium discoideum (Stevens \& Winther, 1979, Tabor \& Tabor, 1985), Mucor racemosus (Inderlied et al., 1980), Mucor rouxii and Mucor bacilliformis (Calvo-Mendez et al., 1987; Martinez-Pacheco et al., 1989). Similarly, the transition of the yeast to mycelial cells in $Y$. lipolytica was accompanied by a transient increase in the levels of the enzyme. These results agree with the observation that ODC activity increased during the yeast-to-mycelium transition of $M$. racemosus (Inderlied et al., 1980) and M. rouxii (Martinez-Pacheco et al., 1989). Associated with the increase in ODC activity, reinitiation of active growth of the fungus was accompanied by an increase in the levels of polyamines. This increase was more noticeable for the mycelial than the yeast form.

Three inhibitors of ODC which have different modes of action all inhibited the yeast-to-mycelium transition of $Y$. lipolytica when added at concentrations which inhibited growth only slightly or not at all. DAB is a competitive inhibitor, and an analogue of putrescine, the ODC product. DAB inhibits ODC from different systems including A. nidulans (Stevens et al., 1977) and M. rouxii and $M$. bacilliformis (Ruiz-Herrera \& Calvo-Mendez,
1987). DFMO is an irreversible inhibitor which binds covalently to the enzyme (Metcalf et al., 1978). Methylornithine is an analogue of the substrate and a competitive inhibitor of ODC (Mamont et al., 1976). These results agree with those obtained previously by our group. ODC inhibitors block the mycelial-to-yeast transition of M. rouxii (Martinez-Pacheco et al., 1989) and C.albicans (Martinez et al., 1990), and the germination of Mucoraceous fungi (Ruiz-Herrera \& CalvoMendez, 1987). In agreement with the observations made in this latter system, the effect of DAB (and the other two ODC inhibitors) on the dimorphic transition of Y. lipolytica was restricted to a short period of time, immediately after the application of the morphogenetic stimulus and long before the appearance of any morphological indication of mycelial growth. When added after this critical period, which appeared to correspond to the transitory elevation of ODC activity, the drugs had no effect on mycelial growth. When cells were pre-grown in the presence of $\mathrm{DAB}$, mycelial induction by the normal protocol followed in this study was prevented. It is probable that the drug is accumulated in the cells and prevents polyamine build-up during the induction period.

The data discussed above indicate that the effect of ODC inhibitors is due to interference with polyamine synthesis. Further evidence for this hypothesis is provided by the reversal of the DAB effect by the addition of putrescine. The sequential order of addition of both compounds, DAB during growth of the inoculum, and putrescine after transfer to GlcNAc medium, counters the possible criticism that putrescine is effective because it prevents the entrance of the inhibitor into the cell. In C. albicans, DFMO depleted polyamine pools after $20 \mathrm{~h}$ of exposure (Pfaller et al., 1988). Polyamines are growth factors required for many different cells (reviews by Tabor \& Tabor, 1976, 1984). This creates a paradox, since ODC inhibitors should inhibit growth and morphogenesis similarly. This, however is not the case. Using the appropriate drug concentrations, the processes of cellular growth and differentiation can be clearly separated, a phenomenon that we have already demonstrated in M. rouxii (Ruiz-Herrera \& Calvo-Mendez, 1987; Martinez-Pacheco et al., 1989). A possible solution to the paradox is provided by the differential effect of ODC inhibitors on intact compared with permeabilized cells. ODC appears to be located in at least two different cell compartments, only one of which is accessible to the inhibitors. A feasible hypothesis is that the accessible enzyme is somehow related to the morphogenetic phenomenon, whereas the other is essential for growth. We observed that only a fraction of the total cell polyamines are present in a free form and able to diffuse. This fraction, which is only $10-20 \%$ of the total in 
$N$. crassa (Davis et al., 1985) may be the only one involved in differentiative processes (Torrigiani et al., 1987). Similar results which suggest the presence of ODC in more than one cell compartment have been obtained in $M$. rouxii (M. Martinez-Pacheco \& J. Ruiz-Herrera, unpublished results).

The precise mode of action of polyamines in differentiation remains unknown. Recently, we have suggested that polyamines have a negative effect on DNA methylation (Cano et al., 1989), the latter being associated with the regulation of gene expression in different systems (Dynan, 1989; Razin et al., 1984) including fungi (Goyon \& Faugeron, 1989; Selker et al., 1987a,b). In agreement with higher eukaryotes, it has been suggested that DNA methylation plays an important role in fungal development (Juppe et al., 1986; Magill \& Magill, 1986; Russell et al., $1987 a, b$ ). Solid evidence for this hypothesis was provided recently in the $M$. rouxii system where the effect of DNA hypomethylation and DAB inhibition were pinpointed to transcription of specific mRNAs (Cano-Canchola et al., 1992). In agreement with our proposal on the mode of action of polyamines, it was observed that 5-azacytidine reverses the effect of DAB in Yarrowia. When cells were pre-grown in the presence of the optimal concentration of $\mathrm{AC}$, further addition of DAB had only a slight inhibitory effect on mycelial formation. AC is a cytosine analogue which is incorporated into DNA and inhibits its methylation, apparently binding to methyltransferases (Tanaka et al., 1980; Taylor \& Jones, 1982). AC incorporation into DNA leads to gene expression in cells where it does not normally occur (Jones, 1985; Felsenfeld \& McGhee, 1982). The fact that AC addition does not induce mycelial formation in Yarrowia indicates that DNA hypomethylation by itself is only a pre-requisite which permits the cell to become responsive to the morphogenetic stimulus. This result agrees with our previous observation that $A C$ counteracts the inhibition in spore germination brought about by $\mathrm{DAB}$, but is unable to accelerate germ tube formation (Cano et al., 1988).

$\alpha$-Difluoromethylornithine was a generous gift from $\operatorname{Dr} P$. P. McCann from the Merrell-Dow Research Institute. This investigation was supported in part by The Consejo Nacional de Ciencia y Tecnologia, Mexico, and Grant Cl1*.0631.M from the Commission of European Communities. J.R.H. and C.C.C. are Mexican National Investigators.

\section{References}

ADAMS, B. G. (1972). Method for decryptification of $\beta$-glucosidase in yeast with dimethyl sulfoxide. Analytical Biochemistry 45, 137-146.

BARTNICKI-GARCIA, S. (1963). Symposium on biochemical bases of morphogenesis in fungi. III. Mold-yeast dimorphism of Mucor. Bacteriological Reviews 27, 293-304.

Calvo-Mendez, C., Martinez-Pacheco, M. \& Ruiz-Herrera, J.
(1987). Regulation of ornithine decarboxylase activity in Mucor bacilliformis and Mucor rouxii. Experimental Mycology 11, 270-277.

Cano, C., Herrera-Estrella, L. \& Ruiz-Herrera, J. (1988). DNA methylation and polyamines in regulation of development of the fungus Mucor rouxii. Journal of Bacteriology 170, 5946-5948.

Cano-Canchola, C., Sosa, L., Fonzi, W., Sypherd, P. \& RuizHERRERA, J. (1992). Developmental regulation of CUP gene expression through DNA methylation in Mucor spp. Journal of Bacteriology 174, 362-366.

CHENG, S. C. \& OGRYDZiak, D. M. (1987). Processing and secretion of the Yarrowia lipolytica RNase. Journal of Bacteriology 169, 14331440.

Dabrowa, N. \& HowaRD, D. H. (1984). Heat shock and heat stroke proteins observed during germination of the blastoconidia of Candida albicans. Infection and Immunity 44, 537-539.

Davis, R. H., Krasner, G. N., Digangi, J. J. \& Ristow, J. L. (1985). Distinct roles of putrescine and spermidine in the regulation of ornithine decarboxylase in Neurospora crassa. Proceedings of the National Academy of Sciences of the United States of America 82, 4105-4109.

DYNAN, W. S. (1989). Understanding the molecular mechanism by which methylation influences gene expression. Trends in Genetics $\mathbf{5}$, 35-36.

Felsenfeld, G. \& MCGhEe, (1982). Methylation and gene control. Nature, London 296, 602-603.

Gaillardin, C. M., Charoy, V. \& Heslot, H. (1973). A study of copulation, sporulation and meiotic segregation in Candida lipolytica. Archives of Microbiology 92, 69-83.

Gaillardin, C. M., Fournier, P., Sylvestre, G. \& Heslot, H. (1976). Mutants of Saccharomycopsis lipolytica defective in lysine catabolism. Journal of Bacteriology 125, 48-57.

GoYON, C. \& FAUGERON, G. (1989). Targeted transformation of Ascobolus immersus and de novo methylation of the resulting duplicated DNA sequences. Molecular and Cellular Biology 9, 2819-2827.

HERBY, O. (1981). Role of polyamines in the control of cell proliferation and differentiation. Differentiation 14, 1-20.

INDERLIED, C. B., CihlaR, R. L. \& SyPheRD, P. S. (1980). Regulation of ornithine decarboxylase during morphogenesis of Mucor racemosus. Journal of Bacteriology 141, 699-706.

JONES, P. A. (1985). Altering gene expression with 5-azacytidine. Cell 40, 485-486.

Juppe, E. R., Magill, J. M. \& Magill, C. W. (1986). Stage-specific DNA methylation in a fungal plant pathogen. Journal of Bacteriology $165,420-423$.

LINDQUisT, S. (1986). The heat-shock response. Annual Review of Biochemistry 55, 1151-1191.

Magill, J. M. \& Magill, C. W. (1989). DNA methylation in fungi. Developmental Genetics 10, 63-69.

Mamont, P. S., Böhlen, P., McCann, P. P., Bey, P., Shubar, F. \& TARDIFF, C. (1976). $\alpha$-Methylornithine, a potent competitive inhibitor of ornithine decarboxylase blocks proliferation of rat hepatoma cells in culture. Proceedings of the National Academy of Sciences of the United States of America 73, 1626-1630.

Martinez, J. P., Lopez-Ribot, J. L., Gil, M. L., Sentandreu, R. \& Ruzz-HerRerA, J. (1990). Inhibition of the dimorphic transition of Candida albicans by the ornithine decarboxylase inhibitor, 1,4diaminobutanone: alterations in the glycoprotein composition of the cell wall. Journal of General Microbiology 136, 1937-1943.

Martinez-Pacheco, M., Rodriguez, G., Reyna, G., Calvo-Mendez, C. \& Ruiz-Herrera, J. (1989). Inhibition of the yeast-mycelial transition and the phorogenesis of Mucorales by diamino butanone. Archives of Microbiology 151, 10-14.

Metcalf, B. W., Bey, P., Danzin, C., Jung, M. J., Casara, P. \& VEVERT, J. P. (1978). Catalytic irreversible inhibition of mammalian ornithine decarboxylase (EC 4.1.1.17) by substrate and product analogues. Journal of the American Chemical Society 100, 2551-2553. ODDs, F. C. (1988). Candida and Candidosis. London: Bailliere Tyndall.

OGR YDZiaK, D., Bassel, J., Contopoulou, R. \& Mortimer, R. (1978). Development of genetic techniques and the genetic map of the yeast Saccharomycopsis lipolytica. Molecular and General Genetics 163, 229-239. 
Pfaller, M. A., Riley, J. \& Gerarden, T. (1988). Polyamine depletion and growth inhibition in Candida albicans and Candida tropicalis by $\alpha$-difluoromethyl ornithine and cyclohexylamine. Journal of Medical and Veterinary Mycology 26, 119-126.

Razin, A., Cedar, H. \& RigGS, A. D. (Eds.) (1984). DNA Methylation: Biochemistry and Biological Significance. New York: SpringerVerlag.

Rodriguez, C. \& Dominguez, A. (1984). The growth and characteristics of Saccharomycopsis lipolytica: morphology and induction of mycelium formation. Canadian Journal of Microbiology 30, 605-612.

RuzZ-Herrera, J. \& Calvo-Mendez, C. (1987). Effect of ornithine decarboxylase inhibitors on the germination of sporangiospores of Mucorales. Experimental Mycology 11, 287-296.

Russell, P. J., Rodland, K. D., Rachlin, E. M. \& McCloskey, J. A. (1987a). Differential DNA methylation during the vegetative life cycle of Neurospora crassa. Journal of Bacteriology 169, 2902-2905.

Russell, P. J., Welsch, J. A., RaChlin, E. M. \& MCCloskey, J. A. $(1987 b)$. Different levels of DNA methylation in yeast and mycelial forms of Candida albicans. Journal of Bacteriology 169, 4393-4395.

Selker, E. U., Cambareri, E. B., Jansen, B. C. \& HaAck, K. R. $(1987 a)$. Rearrangement of duplicated DNA in specialized cells of Neurospora. Cell 51, 741-752.

Selker, E. U., Jensen, B. C. \& Richardson, G. A. (1987 b). A portable signal causing faithful DNA methylation de novo in Neurospora. Science 238, 48-53.

Simonetti, N., Strippoli, V. \& Cassone, A. (1984). Yeast-mycelial conversion induced by $N$-acetyl-D-glucosamine in Candida albicans. Nature, London 250, 344-346.

Sissions, C. H. (1976). Improved technique for accurate and convenient assay of biological reactions liberating $\mathrm{CO}_{2}$. Analytical Biochemistry 70, 454462.

Smith, T. A. (1985). Polyamines. Annual Review of Plant Physiology 36, 117-143.
Soll, D. R. (1985). Candida albicans. In Fungal Dimorphism: With Emphasis on Fungi Pathogenic to Humans, pp. 167-195. Edited by P. J. Szaniszlo. New York: Plenum.

Stevens, L., McKinnon, I. M. \& Winther, M. D. (1977). The effects of 1,4-diaminobutanone on polyamine biosynthesis in Aspergillus nidulans. FEBS Letters 75, 180-182.

SteVEnS, L. \& WintheR, M. D. (1979). Spermine, spermidine and putrescine in fungal dimorphism. Advances in Microbial Physiology 19, 63-148.

Szaniszlo, J. P. (Ed.). (1985). Fungal Dimorphism: With Emphasis on Fungi Pathogenic to Humans. New York: Plenum.

TABOR, C. W. \& TABOR, H. (1976). 1,4-Diaminobutane (putrescine), spermidine and spermine. Annual Review of Biochemistry 45, 285-306.

TABOR, C. W. \& TABOR, H. (1984). Polyamines. Annual Review of Biochemistry 53, 749-790.

TABOR, C. W. \& TABOR, H. (1985). Polyamines in microorganisms. Microbiological Reviews 49, 81-89.

Tanaka, M., Hibasami, H., NaGai, J. \& Ikeda, T. (1980). Effects of 5azacytidine on DNA methylation in Ehrlich's ascites tumor cells. Australian Journal of Experimental Biology and Medical Sciences 58, 391-396.

TAYLOR, S. M. \& JoNES, P. A. (1982). Mechanism of action of eukaryotic DNA methyltransferase. Use of azacytidine-containing DNA. Journal of Molecular Biology 162, 679-692.

Torrigiani, P., Altamura, M. M., Capitani, F., Serafini-Fracassini, D. \& BAGNI, N. (1989). De novo root formation in thin cell layers of tobacco: changes in free and bound polyamines. Physiologia Plantarum 77, 294-301.

Wickerham, L. J., Kurtzman, C. P. \& Herman, A. I. (1970). Sexual reproduction in Candida lipolytica. Science $167,1141$.

ZeUTHEN, M. L. \& HowARD, D. H. (1984). Thermotolerance and the heat-shock response in Candida albicans. Journal of General Microbiology 135, 2509-2518. 